\title{
Using the Kolb's Experiential Learning Cycle to Understand the Application of One Health Competencies to Solving Global Health Challenges; A Tracer Study Among AFROHUN-Uganda Alumni
}

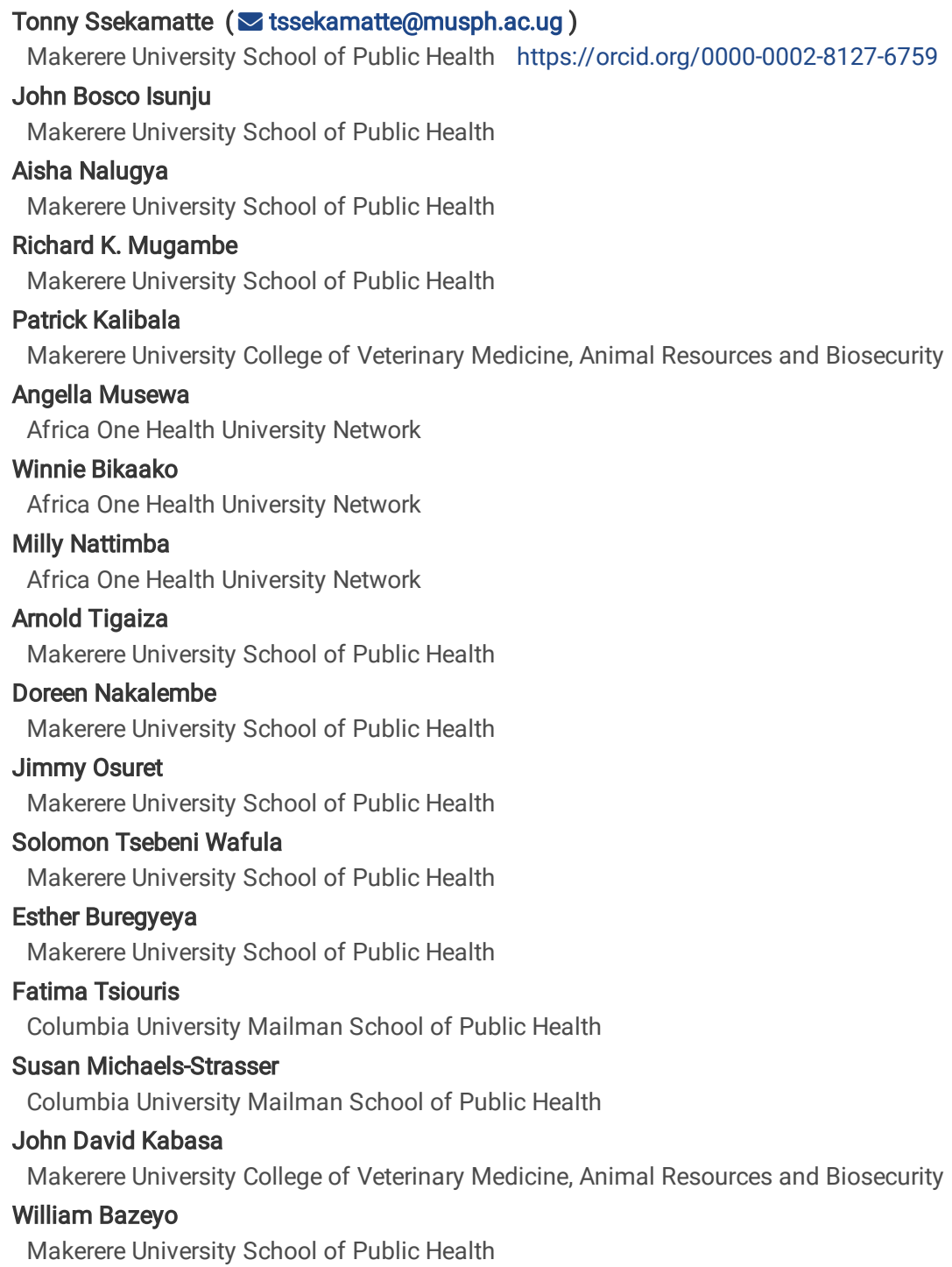




\section{Abstract}

\section{Background}

The Africa One Health University Network (AFROHUN) with support from the United States Agency for International Development (USAID), has since 2012 conducted pre and in-service One health $(\mathrm{OH})$ trainings with the objective of improving global health security through a well-trained multidisciplinary health workforce. These trainings aim to build $\mathrm{OH}$ competencies among participants with the ultimate goal of promoting a multidisciplinary approach to solving global health challenges. Despite these trainings, there is limited documentation of the extent of acquisition and application of the One Health competencies at workplaces. This tracer study established the extent of acquisition and application of the One Health competencies by the AFROHUN-Uganda alumni.

\section{Methods}

A cross-sectional study was conducted among a random sample of 182 AFROHUN-Uganda alumni of 2013-2017. A blended approach of interviewer and selfadministered was used during data collection. Virtual interviews using zoom and skype, and phone interviews with alumni were conducted when face-to-face interviews were not possible. Data were collected electronically, with the aid of the KoboCollect mobile application, pre-installed on android enabled devices. Data were analysed using STATA14.0.

\section{Results}

The majority of respondents, $78.6 \%(143 / 182)$ had jobs that required application of One Health knowledge and skills, 95.6\% (174/182) had learned employable skills from $\mathrm{OH}$ activities and $89.6 \%$ (163/182) had applied such skills when searching for employment. About $21.7 \%(34 / 180)$ to a very high extent required One Health field-specific theoretical knowledge at their workplaces, $27.4 \%(43 / 80)$ to a very high extent required One Health field-specific practical knowledge/skills, 42.7\% (67/180) to a high extent required a change in attitude and perceptions towards working with people from different disciplines, $49.0 \%$ (77/180) required collaboration and networking skills, and more than half, $51.0 \%(80 / 180)$ required team building skills.

\section{Conclusion}

The majority of One Health alumni to a very high extent acquired and applied One Health competences such as teamwork, effective communication, community entry and engagement, report writing and problem-solving skills. This study revealed the significant contribution of the AFROHUN Uganda OH activities towards supportive work environments, and highlights areas of improvement such as supporting the trainees to acquire people-management skills, innovation, and an entrepreneurial mind set.

\section{Background}

The increase in global health challenges is linked to the close interaction between humans, animals and the environment (1). This close interaction is often precipitated by population pressure, urbanization, advances in transport, trade and animal industry, deforestation, climate change, and encroachment on wildlife habitats, and has led to an increase in the transmission of emerging and re-emerging infectious diseases, including Coronavirus disease (COVID-19), and hemorrhagic fevers such as Ebola virus disease (EVD) and Marburg $(2,3)$. Other factors contributing to the emergence and re-emergence of infectious diseases include increased exposure of humans to disease vectors and reservoirs, antimicrobial resistance, weak surveillance systems and limited laboratory diagnostic capacity $(4,5)$.

The emergence and re-emergence of pandemics such as severe acute respiratory syndrome virus (SARS), the H1N1 influenza pandemic, EVD and COVID-19 has had reverberating economic and social consequences, both locally and at global level (6). Most notably, these pandemics have led to a loss of livelihoods consequently leading to poverty and inequalities, weakening of the healthcare systems, and loss of lives (7). For instance, the 2003 SARS outbreak led to 8,098 cases and 774 deaths, the 2009 H1N1 led to 151,700-575,400 deaths, the 2014-2016 EVD led to 28,616 cases of EVD and 11,310 deaths, while the current COVID-19 pandemic has so far claimed 4,690,186 lives globally (8-11). Uganda is a hotspot and has experienced several emerging and re-emerging infectious disease outbreaks $(5,12-17)$. In addition to the current COVID-19 pandemic that has resulted in 122,405 cases and 3,132 deaths as of September 2021(18), the 2000 EVD outbreak in Uganda resulted in 425 cases and 224 deaths (19). These outbreaks have had a high case fatality rate. The case fatality rate has been as high as $75 \%$ for EVD $(13,19), 100 \%$ for Marburg $(15)$ and $36 \%$ for Crimean-Congo hemorrhagic fever $(20)$. The increasing number of global health challenges has made the application of the one health $(\mathrm{OH})$ approach to health promotion and protection inevitable $(1,21-24)$.

The $\mathrm{OH}$ approach, defined as a collaborative, multisectoral, and transdisciplinary approach in which stakeholders at local, regional, national, and global levels work together to achieve optimal health for humans, animals and their shared environment (25), is increasingly vital in the prediction, detection, prevention and response to global health challenges (26). The $\mathrm{OH}$ approach strives to improve global health security by building a multidisciplinary health workforce. Such a workforce requires knowledge and critical skills to counter infectious disease threats and eliminate the current global barriers that exist because of disciplinary silos $(27,28)$. The $\mathrm{OH}$ approach brings together public health professionals, veterinarians, agricultural scientists, anthropologists, economists, educators, engineers, entomologists, epidemiologists, hydrologists, microbiologists, nutritionists, physicians, and sociologists among other cadres to work collaboratively to attain human, animal and environmental health (21).

The multidisciplinary and transdisciplinary, and collaborative nature of $\mathrm{OH}$ requires knowledge, skills and competencies, processes and institutions that facilitate policy and operations to be co-managed and co-delivered across jurisdictions (29). Although vital, $\mathrm{OH}$ competencies required to build successful teams and programs are often overlooked. Most of the discussion on developing the $\mathrm{OH}$ workforce focuses on creating cross-disciplinary awareness and technical skills (29) rather than soft skills such as leadership, communication and informatics, systems thinking and management among others (30-33). To address this challenge, the Africa One Health University Network (AFROHUN) (formerly One Health Central and Eastern Africa (OHCEA), through its One Health 
Workforce $(\mathrm{OHW})$ and One Health Workforce next generation projects undertook competence-based training to enhance the knowledge and skill set of the preand in-service workforce in its network of 9 member countries and 18 universities $(1,2)$.

AFROHUN uses a more integrative and dynamic education system to match global health needs and to produce a workforce that can effectively and efficiently predict, detect and respond to complex global health challenges (27). To achieve this, AFROHUN developed 16 training modules that aim to address the training needs of different sectors and disciplines (34). The modules emphasize teamwork, community engagement, research and effective communication across disciplines (34). The one health trainings incorporate both theoretical and experiential learning with the view of equipping the workforce with the basic technical and non-technical skills and competencies that can complement their specific areas of expertise necessary for One Health practitioners, regardless of discipline (27).

In order to build a more sustainable workforce, AFROHUN together with partner institutions of higher learning provides scholarships, graduate fellowships and residencies. AFROHUN, through the $\mathrm{OH}$ clubs, provides students with an opportunity to engage in outbreak investigation. In addition, through the $\mathrm{OH}$ Institute, it conducts $\mathrm{OH}$ field placements in which students of the various disciplines live and work together in small multidisciplinary teams in the community (27). Together with the different professionals in the field, supervisors and community members, the multi-disciplinary team of students once placed, embarks on community assessments to identify key health problems in the communities of placement (35). This is followed by the implementation of activities aiming at solving these challenges as well as routine monitoring and evaluation.

While numerous $\mathrm{OH}$ programs/trainings and research activities have been carried out among academic, non-academic, government, corporate, and non-profit entities (36), there has been little progress in understanding the extent of acquisition and application of the OH competencies. This tracer study was based on Kolb's experiential Learning Cycle (37) and the systems theory framework (STF) of career development (38) to establish the extent to which the AFROHUNUganda alumni acquired and applied the $\mathrm{OH}$ competencies. Kolb's cycle suggests that effective learning is achieved when a participant obtains a concrete experience of the subject matter followed by (2) observation of and reflection on that experience which leads to (3) the formation of abstract concepts (analysis) and generalizations (conclusions) which are then (4) used to test hypothesis in future situations, resulting in new work experiences. The STF of career development suggests that career development is a dynamic process, depicted through its process influences, change over time and chance (39).

\section{Methods}

\section{Study design, setting and population}

A cross-sectional study utilizing quantitative data collection methods was used to establish the extent of acquisition and application of One Health competencies among AFROHUN-Uganda alumni from the 2013-2018 cohorts of Makerere University and Mbarara University of Science and Technology. AFROHUN is an international University network of 27 schools of Public Health, pathobiology, veterinary medicine, environmental sciences, and medicine that are collaborating to build $\mathrm{OH}$ capacity in 9 countries in the Eastern, Central and West African Regions (34). These countries include the Democratic Republic of Congo, Kenya, Rwanda, Senegal, Côte D'Ivoire, Tanzania and Uganda $(34,40)$. Each of the member countries has a country office which coordinates OH activities locally. The Uganda country office which is hosted at Makerere University coordinates $\mathrm{OH}$ activities in its constituent colleges and Mbarara University of Science and Technology (MUST).

Makerere University is one of the oldest and most prestigious universities in Africa, and is comprised of nine colleges, offering programmes for about 36,000 undergraduates and 4,000 postgraduates (41). MUST is one of the 8 public universities in Uganda and was opened in October 1989. MUST had a total of six faculties and two institutes (42). Makerere University and MUST through their different colleges and faculties have been implementing pre-service OH capacity building initiatives including undergraduate field attachments, graduate fellowships, outbreak investigations, the Students' OH innovation clubs, small grants to support research and innovations and cross-college collaborative training approaches (1). This is aimed at fostering $\mathrm{OH}$ competencies among students who are future practitioners (1)

\section{Description of $\mathrm{OH}$ activities}

AFROHUN developed a One Health Institute $(\mathrm{OHI})$ intended to train and transform the knowledge of young interdisciplinary teams of undergraduate and graduate students, in detection, prevention and response to infectious disease threats. In the $\mathrm{OH}$, students were engaged through didactic instruction on theoretical principles of $\mathrm{OH}$ (34). OH theoretical principles were explored through 16 training modules designed to address the needs of different sectors and disciplines in managing $\mathrm{OH}$ challenges and were delivered by a multidisciplinary team of faculty $(1,34)$. The multidisciplinary delivery model involved group discussions, role-plays, case studies and simulations (1). This was followed by experiential learning through undergraduate field placements and graduate fellowships $(1,34)$. The undergraduate field attachments involved attaching students to predetermined demo sites which gave them an opportunity to apply the knowledge acquired through theoretical classes. At the demo site, the students embarked on problem identification, prioritization and implementation of multidisciplinary solutions in teams under the supervision of different professionals in the field and community members (35). On the other hand, multidisciplinary fellowship placements for graduate students used a mentorship-training model. Graduate students were placed at selected partner organizations and assigned two mentors (academic and field) to support and guide them to acquire One Health competencies, such as problem-solving, multisectoral communication, community engagement, proposal writing, scientific writing and publication. The small grants, which were offered for both undergraduate and graduate students supported research and innovations specific to addressing $\mathrm{OH}$ challenges. Conversely, the $\mathrm{OH}$ student club is a multidisciplinary team of students in Makerere University which has helped participants develop skills and competencies in OH leadership, collaboration and teamwork, community engagement, research, innovation and scientific communication through innovative intellectual debate and engagement around identified $\mathrm{OH}$ challenges.

\section{Sample size and sampling technique}


The sample size was estimated using the Kish Leslie formula for cross-sectional studies (43). We assumed the proportion of AFROHUN-Uganda alumni who applied $\mathrm{OH}$ competencies at their workplaces at 50\%, a 5\% margin of error and the standard normal deviation at 95\% (1.96), giving a sample size of 384. Since the total number of alumni is only 308 , with the calculated sample size higher by over $5 \%$ of the total population, we applied the sample size formula by Daniels (1999) and obtained 170. Considering a non-response rate of $10 \%$, a total sample size of 189 alumni was obtained.

A simple random sampling technique was used in the selection of the respondents. First, a list of the alumni containing their respective email addresses and phone numbers were obtained from the AFROHUN-Uganda country office and their former colleges. We then used the Ms EXCEL function (RAND formula: =RAND 0) to generate a random sample from that list. In cases where reliable contact details could not be obtained from AFROHUN-Uganda, research assistants requested the respondents to share the contact details of members in their cohort.

\section{Data collection techniques, tools and study variables}

Although face-to-face interviews were considered as the core approach to data collection in this study, virtual interviews were also conducted when necessary. Research assistants emailed links to questionnaires that were self-administered by participants. Besides, phone interviews and online/internet-based interviews using Skype and Zoom were also conducted, depending on the availability and preference of the respondents. These approaches have been successfully applied in existing tracer studies $(44,45)$. We adapted the structured questionnaire used by the National Council for Higher Education (NCHE) to conduct a tracer study of 2005 graduates from five universities and four colleges (45). We tailored the questions to the different fields, regions and employing organizations/ institutions in the study. The questionnaire obtained data on background characteristics such as the age, sex, nature of AFROHUN-Uganda OH activities attended, year of attendance of the activities, and highest level of academic qualification. In addition, data were collected on the extent to which respondents acquired $\mathrm{OH}$ competencies during participation in AFROHUN-Uganda $\mathrm{OH}$ activities, $\mathrm{OH}$ competencies required in their employing organizations/institutions and application of $\mathrm{OH}$ competencies in employing organizations.

\section{Data management and analysis}

Data were collected and entered using Kobo Collect mobile application and synchronized onto the server daily. This allowed for real-time data capture and entry, minimized errors at entry and eased data cleaning. Finally, data were downloaded into Microsoft excel for cleaning. Data cleaning included checking for accuracy, completeness and consistency of data. Data were then exported to Stata version 14.0 software for statistical analysis. Descriptive analyses such as frequencies, proportions, and means (where appropriate) were performed.

\section{Quality control and assurance}

Research assistants (RAs) with a minimum of a Bachelor's degree in Environmental Health Sciences, Social Sciences and other relevant fields were recruited. The Pls recruited only RAs who were well conversant with English given that it's was the main language used by our respondents. All RAs were trained on the study protocol, ethical issues and oriented on the different interviewing techniques to ensure quality data collection. We designed the data entry form with skips and restrictions to ensure quality data entry. The tool was pretested to assess the comprehension and clarity of questions. We also supervised the RAs to ensure that they followed the study protocol and observed ethics during data collection.

\section{Results}

\section{Background characteristics of the 2013-2018 AFROHUN-Uganda alumni}

This study recruited a total of 182 respondents, representing a $96.3 \%$ response rate. Less than half, $41.2 \%(75 / 182)$ were females. The mean age of the respondents was $28.7(\mathrm{SD}=4.6)$, median age was 27 while the modular age was 26 . Nearly three quarters, $74.7 \%(136 / 182)$ were aged below 30 years. The average age at award of the undergraduate degree was 24.6 (SD=2.9). Almost three quarters, $73.6 \%(134 / 182)$ had attained a bachelor's degree, $24.2 \%$ (44/182) and 2.2\% (4/182) had attained masters and postgraduate diploma respectively as their highest level of academic qualification (Table 1$)$. 


\begin{tabular}{|c|c|c|}
\hline Variable & Attribute & $\begin{array}{l}\text { Frequency } \mathrm{N}=182 \\
\text { (\%) }\end{array}$ \\
\hline \multirow[t]{2}{*}{ Sex } & Male & $107(58.8)$ \\
\hline & Female & $75(41.2)$ \\
\hline \multirow[t]{2}{*}{ Age in years } & Below 30 & $136(74.7)$ \\
\hline & 30 and above & $46(25.3)$ \\
\hline \multirow[t]{2}{*}{ Year of attendance of any AFROHUN-Uganda capacity building program } & 2013-2015 & $37(20.3)$ \\
\hline & $2016-2018$ & $145(79.7)$ \\
\hline \multirow{8}{*}{$\begin{array}{l}\text { Nature of AFROHUN-Uganda capacity building activities that the alumni } \\
\text { participated in* }\end{array}$} & $\mathrm{OH}$ field attachment & $163(89.6)$ \\
\hline & OH students' club & $8(4.4)$ \\
\hline & $\begin{array}{l}\text { Master of Veterinary Public Health and } \\
\text { Management }\end{array}$ & $3(1.6)$ \\
\hline & Got a scholarship & $2(1.1)$ \\
\hline & Fellowship & $22(12.1)$ \\
\hline & Outbreak Investigations & $20(11)$ \\
\hline & $\mathrm{OH}$ residency & $2(1.1)$ \\
\hline & Innovations & $11(6)$ \\
\hline \multirow{2}{*}{$\begin{array}{l}\text { Had any other academic qualification prior to the award of the most recent } \\
\text { qualification }\end{array}$} & Yes & $22(12.1)$ \\
\hline & No & $160(87.9)$ \\
\hline \multirow[t]{3}{*}{ Highest academic qualification } & Bachelors & $134(73.6)$ \\
\hline & Masters & $44(24.2)$ \\
\hline & Post Graduate Diploma & $4(2.2)$ \\
\hline \multirow{2}{*}{$\begin{array}{l}\text { Was employed after participation in the AFROHUN-Uganda capacity building } \\
\text { programme }\end{array}$} & Yes & $159(87.4)$ \\
\hline & No & $23(12.6)$ \\
\hline
\end{tabular}

\section{Extent to which respondents acquired One Health competencies during participation in AFROHUN-Uganda One health activities}

Of the 182 participants, $98.9 \%$ (180/182) responded on the extent of acquisition of OH competencies. Almost half, 47.8\% (86/180) to a high extent acquired field-specific theoretical knowledge and field-specific practical knowledge. About $88.3 \%(159 / 180)$, to a high extent acquired change in attitude and perception towards working in multidisciplinary teams. Collaboration skills and communication skills were acquired to a high extent by less than half, $43.3 \%$ ( $78 / 180$ ) and $42.8 \%(77 / 180)$, respectively. More than a third, $42.2 \%(76 / 180)$ and $40.0 \%(72 / 180)$ acquired leadership skills and social skills to a high extent, respectively. About half, 51.1\% (92/180) to a high extent acquired team-building skills. Almost half, 43.9\% (79/180) acquired planning, coordinating and organizing skills to a high extent (Table 2).

\section{Application of One Health competencies in navigating the job market}

The majority of respondents, $78.6 \%$ (143/182) had current jobs that required the application of one health knowledge and skills. Almost all, 95.6\% (174/182) of the respondents learnt employable skills, which enabled them in navigating the job market. The most cited employable skills were: teamwork $84.1 \%$ (153/182), communication skills, and $80.8 \%$ (147/182) community engagement 76.9\% (140/182). The majority, 89.6\% (163/182) of respondents reported that they utilised $\mathrm{OH}$ competencies in the search for employment. Of these, 54.9\% (100/182) applied community engagement while in search for employment, $35.2 \%$ (64/182) applied community entry, project planning and management, 73.6\% (134/182) applied communication skills, and 49.5\% (90/182) applied report writing (Table 3).

\section{One Health competencies required in the alumni's workplaces}

To a very high extent about $21.7 \%$ (34/157) required one health field-specific theoretical knowledge at their workplaces, $27.4 \%$ (43/157) required one health field-specific practical knowledge/skills, 42.7\% (67/157) required a change in attitude and perceptions towards working with people from different disciplines, $49.0 \%(77 / 157)$ required collaboration and networking skills, and more than half, $51.0 \%(80 / 157)$ required team-building skills (Table 4$)$. 
Table 2

Extent of acquisition of $\mathrm{OH}$ competencies among the 2013-2018 AFROHUN-Uganda alumni

\begin{tabular}{|c|c|c|c|c|c|}
\hline \multirow[b]{2}{*}{ OH Competencies } & \multicolumn{5}{|c|}{ Extent of acquisition of $\mathrm{OH}$ competencies $\mathrm{N}=180,(n) \%$} \\
\hline & Very high & High & Some & Limited & Not at all \\
\hline Field-specific theoretical knowledge & $50(27.8)$ & $6(47.8)$ & $40(22.2)$ & $4(2.2)$ & $0(0.0)$ \\
\hline Field-specific practical knowledge/skills & $59(32.8)$ & $86(47.8)$ & $30(16.7)$ & $5(2.7)$ & $0(0.0)$ \\
\hline Attitudinal change towards working with multi-disciplinary teams & $82(45.6)$ & $77(42.8)$ & $17(9.4)$ & $4(2.2)$ & $0(0.0)$ \\
\hline Critical thinking skills & $50(27.8)$ & $84(46.7)$ & $42(23.3)$ & $4(2.2)$ & $0(0.0)$ \\
\hline Creativity & $46(25.6)$ & $95(52.8)$ & $34(18.9)$ & $4(2.2)$ & $1(0.6)$ \\
\hline Collaboration across disciplines & $62(34.4)$ & $78(43.3)$ & $34(18.9)$ & $5(2.8)$ & $1(0.6)$ \\
\hline Communication across disciplines & $69(38.3)$ & $77(42.8)$ & $30(16.7)$ & $4(2.2)$ & $0(0.0)$ \\
\hline Leadership skills & $59(32.8)$ & $76(42.2)$ & $37(20.6)$ & $8(4.4)$ & $0(0.0)$ \\
\hline Social (influencing) skills & $57(31.7)$ & $72(40)$ & $40(22.2)$ & $11(6.1)$ & $0(0.0)$ \\
\hline ICT skills & $22(12.2)$ & $39(21.7)$ & $50(27.8)$ & $51(28.3)$ & $18(10)$ \\
\hline Analytical skills & $30(16.7)$ & $78(43.3)$ & $52(28.9)$ & $18(10)$ & $2(1.1)$ \\
\hline Problem solving skills & $47(26.1)$ & $102(56.7)$ & $23(12.8)$ & $8(4.4)$ & $0(0.0)$ \\
\hline Ability to take initiative/lead & $50(27.8)$ & $78(43.3)$ & $39(21.7)$ & $13(7.2)$ & $0(0.0)$ \\
\hline Entrepreneurial skills & 25 (13.9) & $50(27.8)$ & $57(31.7)$ & $36(20)$ & $12(6.7)$ \\
\hline Team building skills & $65(36.1)$ & $92(51.1)$ & $17(9.4)$ & $5(2.8)$ & $1(0.6)$ \\
\hline People management skills & $52(28.9)$ & $71(39.4)$ & $46(25.6)$ & $11(6.1)$ & $0(0.0)$ \\
\hline Customer orientation skills & $52(28.9)$ & $69(38.3)$ & $42(23.3)$ & $11(6.1)$ & $6(3.3)$ \\
\hline Assertiveness & $36(20.0)$ & $69(38.3)$ & $51(28.3)$ & $18(10)$ & $6(3.3)$ \\
\hline Decisiveness & $36(20.0)$ & $72(40)$ & $56(31.1)$ & $11(6.1)$ & $5(2.8)$ \\
\hline Persistence & $49(27.2)$ & $79(43.9)$ & $36(20.0)$ & $13(7.2)$ & $3(1.7)$ \\
\hline Accuracy, attention to detail & $47(26.1)$ & $71(39.4)$ & $51(28.3)$ & $10(5.6)$ & $1(0.6)$ \\
\hline Planning, coordinating and organizing & $66(36.7)$ & $79(43.9)$ & $31(17.2)$ & $3(1.7)$ & $1(0.6)$ \\
\hline Loyalty and integrity & $56(31.1)$ & $83(46.1)$ & $31(17.2)$ & $9(5.0)$ & $1(0.6)$ \\
\hline Getting personally involved in one health activities & $93(51.7)$ & $63(35)$ & $22(12.2)$ & $2(1.1)$ & $0(0.0)$ \\
\hline Adaptability & $64(35.6)$ & $78(43.3)$ & $32(17.8)$ & $4(2.2)$ & $2(1.1)$ \\
\hline Work ethics and integrity & $63(35.0)$ & $77(42.8)$ & $26(14.4)$ & $14(7.8)$ & $0(0.0)$ \\
\hline Professional approaches to solving workplace challenges & $56(31.1)$ & $74(41.1)$ & $37(20.6)$ & $11(6.1)$ & $2(1.1)$ \\
\hline
\end{tabular}




\begin{tabular}{|c|c|c|}
\hline OH competencies & Category & $\mathrm{N}=182,(\mathrm{n}) \%$ \\
\hline \multirow[t]{3}{*}{ Current job requires application of $\mathrm{OH}$ knowledge and skills } & Yes & $143(78.6)$ \\
\hline & No & $16(8.8)$ \\
\hline & Have never got employed & $23(12.6)$ \\
\hline \multirow[t]{2}{*}{ Learnt any employable skills from the One health activities } & Yes & $174(95.6)$ \\
\hline & No & $8(4.4)$ \\
\hline \multirow[t]{9}{*}{ Employable skills learnt by the respondents* } & Community engagement & $140(76.9)$ \\
\hline & Community entry & $120(67)$ \\
\hline & Project planning and management & $87(47.8)$ \\
\hline & Report writing & $120(65.9)$ \\
\hline & Data analysis & $72(39.6)$ \\
\hline & Communication skills & $147(80.8)$ \\
\hline & Problem-solving skills & $117(64.3)$ \\
\hline & Teamwork & $153(84.1)$ \\
\hline & Other skills & $10(5.5)$ \\
\hline \multirow[t]{2}{*}{ Utilised $\mathrm{OH}$ competencies in the search for employment } & Yes & $163(89.6)$ \\
\hline & No & $19(10.4)$ \\
\hline \multirow[t]{7}{*}{ Employable skills applied by the alumni while in search for employment* } & Community engagement & $100(54.9)$ \\
\hline & Community entry & $64(35.2)$ \\
\hline & Project planning and management & $64(35.2)$ \\
\hline & Report writing & $90(49.5)$ \\
\hline & Data analysis & $47(25.8)$ \\
\hline & Communication skills & $134(73.6)$ \\
\hline & Problem-solving skills & $89(48.9)$ \\
\hline \multirow[t]{2}{*}{ Attended an interview for any job after participating in the AFROHUN-Uganda One health activities } & Yes & $146(80.2)$ \\
\hline & No & $36(19.8)$ \\
\hline \multirow[t]{8}{*}{ Skills required during their most recent job interview* } & Community engagement & $72(39.6)$ \\
\hline & Community entry & $43(23.6)$ \\
\hline & Project planning and management & $48(26.4)$ \\
\hline & Report writing & $64(35.2)$ \\
\hline & Data analysis & $54(29.7)$ \\
\hline & Communication skills & $101(55.5)$ \\
\hline & Problem-solving skills & $84(46.2)$ \\
\hline & Teamwork & $104(57.1)$ \\
\hline \multirow[t]{3}{*}{ Qualified for the job } & Yes & $129(70.9)$ \\
\hline & No & $17(9.3)$ \\
\hline & Did not attend any interview & $36(19.8)$ \\
\hline
\end{tabular}


Table 4

Extent of Application of OH competencies at workplaces by the 2013-2018 AFROHUN-Uganda OH alumni

\begin{tabular}{|c|c|c|c|c|c|}
\hline \multirow[b]{2}{*}{ OH competencies } & \multicolumn{5}{|c|}{ Extent of application of $\mathrm{OH}$ competencies $\mathrm{N}=157$, (n)\% } \\
\hline & Very high & High & Some & Limited & Not at all \\
\hline $\mathrm{OH}$ field-specific theoretical knowledge & $34(21.7)$ & $67(42.7)$ & $38(24.2)$ & $16(10.2)$ & $2(1.3)$ \\
\hline OH field-specific practical skills & $43(27.4)$ & $63(40.1)$ & $38(24.2)$ & $11(7)$ & $2(1.3)$ \\
\hline Attitudinal change towards working with multi-disciplinary teams & $61(38.9)$ & $67(42.7)$ & $22(14)$ & $7(4.5)$ & $0(0.0)$ \\
\hline Critical thinking skills & $67(42.7)$ & $56(35.7)$ & $30(19.1)$ & $4(2.5)$ & $0(0.0)$ \\
\hline Creativity skills & $63(40.1)$ & $62(39.5)$ & $28(17.8)$ & $3(1.9)$ & $1(0.6)$ \\
\hline Collaboration and networking skills & $77(49)$ & $58(36.9)$ & $17(10.8)$ & $5(3.2)$ & $0(0.0)$ \\
\hline Communication skills & $95(60.5)$ & $50(31.5)$ & $10(6.4)$ & $2(1.3)$ & $0(0.0)$ \\
\hline Leadership skills & $69(43.9)$ & $63(40.1)$ & $20(12.7)$ & $5(3.2)$ & $0(0.0)$ \\
\hline Social (influencing) skills & $63(40.1)$ & $60(38.2)$ & $29(18.5)$ & $5(3.2)$ & $0(0.0)$ \\
\hline ICT skills & $67(42.7)$ & $56(35.7)$ & $22(14)$ & $8(5.1)$ & $4(2.5)$ \\
\hline Analytical skills & $62(39.5)$ & $65(41.4)$ & $24(15.3)$ & $6(3.8)$ & $0(0.0)$ \\
\hline Problem-solving skills & $77(49)$ & $61(38.9)$ & $18(11.5)$ & $1(0.6)$ & $0(0.0)$ \\
\hline You are able to take initiative & $58(36.9)$ & $67(42.7)$ & $27(17.2)$ & $5(3.2)$ & $0(0.0)$ \\
\hline Entrepreneurial skills & $32(20.4)$ & $39(24.8)$ & $52(33.1)$ & $25(15.9)$ & $9(5.7)$ \\
\hline Team building skills & $80(51)$ & $54(34.4)$ & $20(12.7)$ & $3(1.9)$ & $0(0.0)$ \\
\hline People management skills & $78(49.7)$ & $55(35)$ & $24(15.3)$ & $62(39.5)$ & $0(0.0)$ \\
\hline Customer orientation skills & $53(33.8)$ & $26(16.6)$ & $12(7.6)$ & $4(2.5)$ & $0(0.0)$ \\
\hline Assertiveness & $55(35)$ & $57(36.3)$ & $40(25.5)$ & $3(1.9)$ & $2(1.3)$ \\
\hline Decisiveness & $65(41.4)$ & $60(38.2)$ & $25(15.9)$ & $5(3.2)$ & $2(1.3)$ \\
\hline Persistence & $71(45.2)$ & $58(36.9)$ & $23(14.6)$ & $4(2.5)$ & $1(0.6)$ \\
\hline Accuracy and attention to detail skills & $79(50.3)$ & $62(39.5)$ & $11(7)$ & $5(3.2)$ & $0(0.0)$ \\
\hline Planning, coordinating and organizing skills & $84(53.5)$ & $54(34.4)$ & $15(9.6)$ & $4(2.5)$ & $0(0.0)$ \\
\hline Loyalty and integrity skills & $90(57.3)$ & $51(32.5)$ & $14(8.9)$ & $2(1.3)$ & $0(0.0)$ \\
\hline You are required to get personally involved into activities & $81(51.6)$ & $64(40.8)$ & $9(5.7)$ & $3(1.9)$ & $0(0.0)$ \\
\hline Adaptability skills & $66(42)$ & $63(40.1)$ & $22(14)$ & $5(3.2)$ & $1(0.6)$ \\
\hline Work ethics and integrity & $95(60.5)$ & $50(31.8)$ & $11(7)$ & $1(0.6)$ & $0(0.0)$ \\
\hline You provide professional solutions to your workplace challenges & $69(43.9)$ & $64(40.8)$ & $21(13.4)$ & $3(1.9)$ & $0(0.0)$ \\
\hline
\end{tabular}

\section{Discussion}

This study established the extent of acquisition and application of the one health competencies among AFROHUN-Uganda OH alumni. The study revealed that majority of the alumni had jobs that required the application of $\mathrm{OH}$ knowledge, skills, and competencies. Alumni were assessed for skills in community entry and engagement, project planning and management, data analysis and report writing, communication, problem solving, and team work during their most recent job interviews. More than three quarters of the alumni acquired field-specific theoretical knowledge and practical skills. In addition, a significant proportion reported a change in attitude and perceptions towards working with individuals from other disciplines.

The current study revealed that almost all the alumni learnt employable skills from $\mathrm{OH}$ activities. The skills reported by the alumni included community entry and engagement, applied communication skills, project planning and management, and report writing. The alumni pointed out that they applied the different skills while in search for employment opportunities. Just like Kolb's experiential learning cycle $(46,47)$, AFROHUN-Uganda OH activities such as the One Health Institute $(\mathrm{OHI})$ and the graduate placement incorporate experiential learning that is intended to enable students to "learn by doing" and by reflecting on their experience, while under supervision. The $\mathrm{OH}$ experiential learning implemented by AFROHUN-Uganda can stimulate academic inquiry by promoting interdisciplinary learning, collaboration, civic engagement, career development, cultural and gender sensitivity, and leadership (46-50). Experiential learning also improves the quality of personal involvement, i.e. the whole-person in both his feeling and cognitive aspects being in the learning event (51-53). The $\mathrm{OH}$ experiential learning process implemented by AFROHUN-Uganda is largely student-led and involves participatory and interactive learning, reflection, abstract conceptualization, and active experimentation. This mode of training helps the students, herein referred to as the alumni, to translate the practical knowledge 
and skills acquired during their training. The knowledge, skills and competencies acquired from the $\mathrm{OH}$ field experiential learning activities can be applied by the alumni at their workplaces.

The study revealed communication, teamwork, community engagement, and problem-solving skills as some of the skills required from the alumni during job interviews. These skills are part and parcel of the one health training offered by AFROHUN to students participating in $\mathrm{OH}$ activities, including the $\mathrm{OHI}$, outbreak investigation and graduate placement (1). The communication skills learnt by the alumni included listening, nonverbal communication, clarity and concision, friendliness among others. Appropriate and effective communication skills are essential in today's workplaces (54, 55). Communication skills help improve customer care in organisations and improve the image of the employer/ organisations. The current study also revealed that teamwork was a skill that was required by employers during job interviews. Teamwork is known to improve the employee's performance. Employees in organisations where teamwork is embraced are more likely to relate better since they have an opportunity to bond with one another. It is worth noting that community engagement and entry was also a critical skill learnt and applied by the alumni. Community engagement and entry is a critical skill in many workplaces as it involves building a strong partnership between community-based organisations or institutions and individuals with the collective vision of benefiting the community/target population. This explains why most organisations required alumni with community engagement skills during the interviews, and the reason as to why nearly three quarters of the alumni qualified for the respective jobs.

More than three-quarters of the alumni enrolled on the study agreed that to a high extent they acquired field-specific theoretical knowledge and practical knowledge/skills from the $\mathrm{OH}$ training programmes. The mode of training employed by AFROHUN involves in-class and virtual sessions which are vital in imparting theoretical knowledge to the alumni. The training also involves field experiential learning which involves students being placed in organisations or institutions that have a vast interest in using the $\mathrm{OH}$ approach in tackling global health challenges. Experiential learning involves students working with the local communities in identifying community challenges and innovatively developing solutions to the identified health challenges. Through experiential learning, students are also given an opportunity to develop innovations and apply for small grants. These avenues help to impart theoretical and practical knowledge and skills. Experiential learning has been shown to improve practical knowledge and skills (56-58), while in-class and virtual sessions are known to improve theoretical knowledge among students (59-61).

A significant proportion of the alumni in the current study agreed that participation in the AFROHUN-Uganda OH activities was instrumental in facilitating their change in attitude and perceptions towards working in multidisciplinary teams. The goal of the $\mathrm{OH}$ training programs is to foster multi-sectoral collaboration and transdisciplinarity. To achieve this goal, AFROHUN-Uganda equips students with knowledge on management, leadership, culture and ethics, communication, systems thinking, and collaboration that are vital in influencing students' attitudes and perceptions towards working with individuals from other disciplines. This finding illustrates the positive stride made by AFROHUN-Uganda in influencing positive behaviours towards collaboration among the different cadre and sectors. A change in attitude and perceptions is widely documented as one of the facilitators of the application of the $\mathrm{OH}$ approach (62, 63).

More than three-quarters of the alumni in the current study agreed that, to a high extent, they had acquired leadership skills. Nearly three-quarters of the alumni mentioned that their jobs required leadership skills. Attainment of optimal health at the environment-human-animal nexus requires effective leadership. In order to achieve the objectives of the $\mathrm{OH}$ approach, it is important that those trained and their colleagues have adequate leadership and management skills such as active listening, empathy, and strategic thinking. Effective leadership skills enable managers to inspire a vision and motivate fellow employees towards achieving one health goals. Effective leadership is critical in enabling managers in empowering team members to work at their full potential and to take responsibility for decision making. Besides, effective leadership is critical for building consensus among disparate sectors and fostering champions for cohesion and change (64). Other roles of leadership in advancing one health are documented by Amuasi, Lucas (64) and Zinsstag, Schelling (65).

\section{Conclusion}

Our study revealed that the majority of the one health alumni had acquired jobs that required the application of one health knowledge and skills such as teamwork, effective communication, community entry and engagement, report writing and problem-solving skills. The competencies acquired by the one health alumni were to a high extent applied at their workplaces. Notably, the $\mathrm{OH}$ activities to a high extent changed the attitude of the alumni towards working in multi-disciplinary teams. This study revealed the significant contribution of the AFROHUN Uganda $\mathrm{OH}$ activities towards supportive work environments and highlights areas of improvement such as supporting the trainees to acquire people-management skills, innovation, and an entrepreneurial mindset.

\section{Abbreviations}

AFROHUN: Africa One Health University Network

\begin{tabular}{ll}
\hline EVD: & Ebola Virus Disease \\
\hline MUST: & Mbarara University of Science and Technology \\
\hline OH: & One Health \\
\hline OHCEA: & One Health Central and Eastern Africa \\
\hline OHI: & One Health Institute \\
\hline STF: & Systems Theory Framework \\
\hline USAID: & United States Agency for International Development
\end{tabular}




\section{Declarations}

\section{Ethics approval and consent to participate}

This study was reviewed and approved by Makerere university school of Public Health Higher Degrees and Research Ethics Committee (HDREC) (protocol number 832). The study was also registered with the Uganda National Council of Science and Technology. Verbal consent was also obtained from all of the study participants. Participation in the study was entirely voluntary and verbal consent was obtained. Privacy and confidentiality were ensured during the study. Participant names, titles and positions and organisations have been de-identified to ensure confidentiality.

\section{Consent to publish}

Not applicable

\section{Availability of data and materials}

The datasets analysed during the current study are available from the corresponding author upon reasonable request.

\section{Competing interests}

The authors declare that they have no competing interests.

\section{Funding}

This study was funded by the United States Agency for International Development (USAID) through the Africa One Health University Network. The study protocol was independently peer-reviewed by the funding body, however, any opinions, conclusions, or recommendations expressed in this article are those of the authors alone, and do not necessarily reflect the views of the funder.

\section{Authors' contributions}

TS, RKM, JBI, AM, EB, JDK and WB conceptualized the study, participated in data collection, analysis and drafting the manuscript. AN, PK, STW, WB,MN, AT, DN, JO, FT and SMS participated in the analysis and drafting of the manuscript. All authors read and approved this manuscript before submission to this journal.

\section{Acknowledgement}

We are indebted to AFROHUN Uganda, the funders of this study. We would like to thank the study participants (alumni) for sparing time to respond to the data collection tool. Special thanks also go to research assistants (Patience Oputan, Nakiggala Joanna and Jonah Ainembabazi) for their invaluable effort in the execution of data collection.

\section{References}

1. Buregyeya E, Atusingwize E, Nsamba P, Nalwadda C, Osuret J, Kalibbala P, et al. Benefits of a community based interdisciplinary learning exposure: A qualitative study of the One Health approach in teaching at Makerere University, Uganda. Research Square; 2020.

2. Buregyeya E, Atusingwize E, Nsamba P, Musoke D, Naigaga I, Kabasa JD, et al. Operationalizing the One Health Approach in Uganda: Challenges and Opportunities. J Epidemiol Glob Health. 2020;10(4):250-7.

3. MOH, MAAIF, UWA, MWE. Uganda One Health Strategic Plan 2018-2022. 2018.

4. Abebe GM. Emerging and Re-Emerging Viral Diseases: The Case of Coronavirus Dis-ease-19 (COVID-19). Int J Virol AIDS. $2020 ; 7: 067$.

5. Nyakarahuka L, Balinandi S, Mulei S, Kyondo J, Tumusiime A, Klena J, et al. Ten outbreaks of rift valley fever in Uganda 2016-2018: epidemiological and laboratory findings. International Journal of Infectious Diseases. 2019;79:4.

6. Chattu VK, Yaya S. Emerging infectious diseases and outbreaks: implications for women's reproductive health and rights in resource-poor settings. Reproductive Health. 2020;17(1):43.

7. ILO, FAO, IFAD, WHO. Impact of COVID-19 on people's livelihoods, their health and our food systems 2020 [Available from: https://www.who.int/news/item/13-10-2020-impact-of-covid-19-on-people's-livelihoods-their-health-and-our-food-systems.

8. CDC. Principles of Epidemiology in Public Health Practice: Centers for Disease Control and Prevention; 2012 May 26, 2021]. Available from: https://www.cdc.gov/csels/dsepd/ss1978/lesson1/section10.html.

9. CDC. SARS Basics Fact Sheet Atlanta: Centres for Disease Control and Prevention; 2017 [Available from: https://www.cdc.gov/sars/about/fs-sars.html. 
10. CDC. 2014-2016 Ebola Outbreak in West Africa Atlanta: Centres for Disease Control and Prevention; 2019 [cited 2021 21-09]. Available from: https://www.cdc.gov/vhf/ebola/history/2014-2016-outbreak/index.html.

11. WHO. WHO Coronavirus (COVID-19) Dashboard. WHO Health Emergency Dashboard 2021 [Available from: https://covid19.who.int/.

12. Kwagonza L, Masiira B, Kyobe-Bosa H, Kadobera D, Atuheire EB, Lubwama B, et al. Outbreak of yellow fever in central and southwestern Uganda, February-may 2016. BMC Infectious Diseases. 2018;18(1):548.

13. Aceng JR, Ario AR, Muruta AN, Makumbi I, Nanyunja M, Komakech I, et al. Uganda's experience in Ebola virus disease outbreak preparedness, $2018-2019$. Globalization and Health. 2020;16(1):24.

14. Migisha R, Kwesiga B, Mirembe BB, Amanya G, Kabwama SN, Kadobera D, et al. Early cases of SARS-CoV-2 infection in Uganda: epidemiology and lessons learned from risk-based testing approaches - March-April 2020. Globalization and Health. 2020;16(1):114.

15. Siya A, Bazeyo W, Tuhebwe D, Tumwine G, Ezama A, Manirakiza L, et al. Lowland grazing and Marburg virus disease (MVD) outbreak in Kween district, Eastern Uganda. BMC Public Health. 2019;19(1):136.

16. Nyakarahuka L, Shoemaker TR, Balinandi S, Chemos G, Kwesiga B, Mulei S, et al. Marburg virus disease outbreak in Kween District Uganda, 2017: Epidemiological and laboratory findings. PLOS Neglected Tropical Diseases. 2019;13(3):e0007257.

17. Polonsky JA, Wamala JF, de Clerck H, Van Herp M, Sprecher A, Porten K, et al. Emerging filoviral disease in Uganda: proposed explanations and research directions. Am J Trop Med Hyg. 2014;90(5):790-3.

18. WHO. WHO Health Emergency Dashboard. COVID-19 Uganda Situation 2021 [cited 2021 22-September]. Available from: https://covid19.who.int/region/afro/country/ug.

19. WHO. How Previous Ebola Virus Disease Outbreaks Helped Uganda Respond to COVID-19 Outbreak 2020 [cited 2021 22-September]. Available from: https://www.afro.who.int/news/how-previous-ebola-virus-disease-outbreaks-helped-uganda-respond-covid-19-outbreak.

20. Mirembe BB, Musewa A, Kadobera D, Kisaakye E, Birungi D, Eurien D, et al. Sporadic outbreaks of crimean-congo haemorrhagic fever in Uganda, July 2018-January 2019. PLOS Neglected Tropical Diseases. 2021;15(3):e0009213.

21. Mazet JA, Clifford DL, Coppolillo PB, Deolalikar AB, Erickson JD, Kazwala RR. A “one health" approach to address emerging zoonoses: the HALI project in Tanzania. PLoS medicine. 2009;6(12):e1000190.

22. Arshad MI, Khan HA, Aslam B, Khan JA. Appraisal of One Health approach amid COVID-19 and zoonotic pandemics: insights for policy decision. Tropical Animal Health and Production. 2021;53(1):1-2.

23. Reddy KS, Mathur MR. Pandemics \& One Health: India's evolving response. Indian Journal of Medical Research. 2021;153(3):245.

24. David P-M, Le Dévédec N, Alary A. Pandemics in the age of the Anthropocene: Is 'planetary health'the answer? Global Public Health. $2021: 1-14$.

25. CDC. One Health Atlanta: Centers for Disease Control and Prevention 2021 [Available from: https://www.cdc.gov/onehealth/index.html.

26. CDC. One Health Basics 2018 [Available from:

https://www.cdc.gov/onehealth/basics/index.html\#: :text=One\%20Health\%20is\%20a\%20collaborative,plants\%2C\%20and\%20their\%20shared\%20environ

27. Amuguni H, Bikaako W, Naigaga I, Bazeyo W. Building a framework for the design and implementation of One Health curricula in East and Central Africa: OHCEAs One Health Training Modules Development Process. One health (Amsterdam, Netherlands). 2018;7:002-2.

28. Steele SG, Booy R, Mor SM. Establishing research priorities to improve the One Health efficacy of Australian general practitioners and veterinarians with regard to zoonoses: A modified Delphi survey. One health (Amsterdam, Netherlands). 2018;6:7-15.

29. Stephen C, Stemshorn B. Leadership, governance and partnerships are essential One Health competencies. One Health. 2016;2:161-3.

30. Frankson R, Hueston W, Christian K, Olson D, Lee M, Valeri L, et al. One Health Core Competency Domains. Frontiers in public health. 2016;4:192-.

31. Amuguni HJ, Mazan M, Kibuuka R. Producing interdisciplinary competent professionals: integrating One Health core competencies into the veterinary curriculum at the University of Rwanda. Journal of veterinary medical education. 2017;44(4):649-59.

32. Stephen C, Stemshorn B. Leadership, governance and partnerships are essential One Health competencies. Elsevier; 2016.

33. Larsen RJ. Shared Curricula and Competencies in One Health and Health Professions Education. Medical Science Educator. 2021;31(1):249-52.

34. AFROHUN, USAID. Introducing and Welcoming you to Africa One Health University Network (AFROHUN) 2020 [Available from: https://afrohun.org/.

35. Rwego IB, Babalobi OO, Musotsi P, Nzietchueng S, Tiambo CK, Kabasa JD, et al. One Health capacity building in sub-Saharan Africa. Infection ecology \& epidemiology. 2016;6:34032-.

36. Stroud C, Kaplan B, Logan JE, Gray GC. One Health training, research, and outreach in North America. Infection ecology \& epidemiology. 2016;6:33680-.

37. Abdulwahed M, Nagy ZK. Applying Kolb's experiential learning cycle for laboratory education. Journal of engineering education. 2009;98(3):283-94.

38. Patton W, McMahon M. Career development and systems theory: A new relationship: Thomson Brooks/Cole Publishing Co; 1999.

39. Patton W, McMahon M. The systems theory framework of career development and counseling: Connecting theory and practice. International Journal for the Advancement of Counselling. 2006;28(2):153-66.

40. Killewo J, Bazeyo W, Mdegela R. One Health Central and Eastern Africa: Historical and Future Perspectives. International Encyclopedia of Public Health. 2017:342-7.

41. Makerere University. About MAK 2021 [Available from: https://www.mak.ac.ug/about-makerere.

42. MUST. About Mbarara University of Science \& Technology 2021 [Available from: https://www.must.ac.ug/about-must/.

43. Kish L. Sampling organizations and groups of unequal sizes. American sociological review. 1965:564-72. 
44. Macatangay L. Tracer Study of BSCS Graduates of Lyceum of The Philippines University from 2004-2009. Academic Research International. 2013;4(5):361.

45. NCHE. Tracer study of 2005 graduates from five universities and four colleges. THE NATIONAL COUNCIL FOR HIGHER EDUCATION 2013.

46. Kolb DA. Experience as the source of learning and development. Upper Sadle River: Prentice Hall. 1984.

47. Kolb DA. Experiential learning: Experience as the source of learning and development: FT press; 2014.

48. Smith A. Experiential learning: Edward Elgar Publishing Limited; 2016.

49. Anwar G, Abdullah NN. Inspiring future entrepreneurs: The effect of experiential learning on the entrepreneurial intention at higher education. International Journal of English Literature and Social Sciences. 2021;6.

50. Yang H, Cheung C, Li W. Intercultural Communication Competency Practices in the Hotel Industry. Journal of China Tourism Research. $2020: 1-23$.

51. Burke D. Experiential Learning Theory. How Doctors Think and Learn: Springer; 2020. p. 29-37.

52. Latifah S. Learning Styles According to David Kolb. Educia Journal. 2021;1(1):1-4.

53. Stock KL, Kolb DA, Chairman E. The Experiencing Scale: An Experiential Learning Gauge of Engagement in Learning. 2020.

54. Alyammahi A, Alshurideh M, Al Kurdi B, Salloum SA, editors. The impacts of communication ethics on workplace decision making and productivity. International Conference on Advanced Intelligent Systems and Informatics; 2020: Springer.

55. Robles MM. "Ups and Downs" and "Ins and Outs" of Organizational Communication. Business Communication Research and Practice. 2020;3(1):1-3.

56. McClaren BJ, Crellin E, Janinski M, Nisselle AE, Ng L, Metcalfe SA, et al. Preparing medical specialists for genomic medicine: continuing education should include opportunities for experiential learning. Frontiers in genetics. 2020;11:151.

57. Pherson-Geyser M. The Use of Experiential Learning as a Teaching Strategy in Life Sciences. International Journal of Instruction. 2020;13(3):877-94.

58. Gershfeld-Litvin A. Multi-learning experience course for psychology undergraduates: Combining experiential learning and theory-based research learning about disabilities. Journal of Disability Studies. 2020;6(1):36-9.

59. Morice A, Jablon E, Delevaque C, Khonsari RH, Picard A, Kadlub N. Virtual versus traditional classroom on facial traumatology learning: Evaluation of medical student's knowledge acquisition and satisfaction. Journal of Stomatology, Oral and Maxillofacial Surgery. 2020;121(6):642-5.

60. Wolff CE, Jarodzka H, Boshuizen HPA. Classroom Management Scripts: a Theoretical Model Contrasting Expert and Novice Teachers' Knowledge and Awareness of Classroom Events. Educational Psychology Review. 2021;33(1):131-48.

61. Encarnacion RFE, Galang AAD, Hallar BJA. The Impact and Effectiveness of E-Learning on Teaching and Learning. Online Submission. $2021 ; 5(1): 383-97$.

62. Dos S Ribeiro C, van de Burgwal LHM, Regeer BJ. Overcoming challenges for designing and implementing the One Health approach: A systematic review of the literature. One health (Amsterdam, Netherlands). 2019;7:100085-.

63. Kingsley J, Patrick R, Horwitz P, Parkes M, Jenkins A, Massy C, et al. Exploring Ecosystems and Health by Shifting to a Regional Focus: Perspectives from the Oceania EcoHealth Chapter. Int J Environ Res Public Health. 2015;12(10):12706-22.

64. Amuasi JH, Lucas T, Horton R, Winkler AS. Reconnecting for our future: the lancet one health commission. The Lancet. 2020;395(10235):1469-71. 65. Zinsstag J, Schelling E, Crump L, Whittaker M, Tanner M, Stephen C. One Health: the theory and practice of integrated health approaches: CABI; 2020. 